Article

\title{
A Combined System Using Lagoons and Constructed Wetlands for Swine Wastewater Treatment
}

\author{
Pietro Denisi (D), Nicola Biondo, Giuseppe Bombino, Adele Folino $\mathbb{D}$, Demetrio Antonio Zema *(D) \\ and Santo Marcello Zimbone
}

check for

updates

Citation: Denisi, P.; Biondo, N.; Bombino, G.; Folino, A.; Zema, D.A.; Zimbone, S.M. A Combined System Using Lagoons and Constructed Wetlands for Swine Wastewater Treatment. Sustainability 2021, 13, 12390. https://doi.org/10.3390/ su132212390

Academic Editors: Muhammad Arslan, Muhammad Afzal and Naser A. Anjum

Received: 30 September 2021 Accepted: 6 November 2021 Published: 10 November 2021

Publisher's Note: MDPI stays neutral with regard to jurisdictional claims in published maps and institutional affiliations.

Copyright: (c) 2021 by the authors. Licensee MDPI, Basel, Switzerland. This article is an open access article distributed under the terms and conditions of the Creative Commons Attribution (CC BY) license (https:/ / creativecommons.org/licenses/by/ $4.0 /)$.
Department Agraria, Mediterranea University of Reggio Calabria, Località Feo di Vito, I-89122 Reggio Calabria, Italy; pietro.denisi@unirc.it (P.D.); nicolabiondo83@gmail.com (N.B.); giuseppe.bombino@unirc.it (G.B.); adelefolino@alice.it (A.F.); smzimbone@unirc.it (S.M.Z.)

* Correspondence: dzema@unirc.it

\begin{abstract}
This study evaluates the depuration efficiency of a combined system consisting of lagoons (with aerated and non-aerated tanks) and CWs (with Typha latifolia L.) working at pilot scale for treating SW under two recirculation rates (RRs, 4:1 and 10:1) of the CW effluent. The combined system removed about $99 \%$ of the total suspended solids and organic matter, and from $80 \%$ to $95 \%$ of the total nitrogen at both tested RRs. The lagoon system was effective as a pre-treatment of SW, particularly for nitrogen removal. It is convenient to adopt the higher RR, since nitrogen removal can be increased by approximately $20 \%$. The irrigation of the CWs with SW did not generally determine the phyto-toxic effects on Typha latifolia L., except at the start of the experiment and under the lower RR. Despite the limited spatial and temporal scale of this investigation, these results provide a starting point for the use of V-SSF CWs to treat livestock wastewater with a high pollution potential (such as SW).
\end{abstract}

Keywords: livestock wastewater; Typha latifolia L.; V-SSF systems; total nitrogen; COD; total suspended solids

\section{Introduction}

The wastewater from livestock breeding farms has a heavy pollution potential for soil and water resources [1,2]. Swine breeding farms make a significant contribution to the production of wastewater. Swine wastewater (hereafter "SW") consists of a blend of urine (about 40-45 kg/day/1000 kg of animal live weight [3]); feces (about $90 \mathrm{~kg} /$ day/1000 kg live weight [3]); water; residues of undigested food; antibiotics; and pathogens, as well as water used to clean the housing sheds [4-6]. To give a rough indication, SW is characterized by a high content of solids (total solids in the range 12.6 to $42.7 \mathrm{~g} / \mathrm{L}$ ), organic matter (chemical oxygen demand, COD, between 16.1 and $56.2 \mathrm{~g} / \mathrm{L}$ ), and nutrients (total nitrogen: 1.5-5.2 g/L; ammonium: $0.9-4.3 \mathrm{~g} / \mathrm{L}$; and total phosphorus: $0.1-1.3 \mathrm{~g} / \mathrm{L})[1,3,7]$. SW also contains other organic xenobiotic substances, such pharmaceuticals [8].

Due to these physico-chemical characteristics and large production, the management of SW can lead to severe environmental pollution [9]. Furthermore, the direct disposal of SW can contaminate surface and ground waters, cause unpleasant odor emissions in the air, and degrade soil quality $[8,10]$. In particular, the high nutrient loads in SW can have undesirable effects on aquatic plant proliferation and the eutrophication of water bodies, as well as direct toxicity due to the high oxygen demand in water [11].

Traditionally, SW is commonly spread to the land as fertilizer, often after lagoon retention [12], but the nutrient loads always exceed the fertilizer requirement of crops with alterations in the nutrient balance of soil [13]. The practice of SW land spreading does not respect the strict rules of many countries on SW management (e.g., the so-called "Nitrate Directive" in Europe) [14]. In other cases, the farmland for SW spreading is insufficient [12]. Several systems have been proposed as alternatives to land spreading: 
(i) aerobic (e.g., sequencing batch reactors and membrane bioreactors) and anaerobic (e.g., anaerobic digesters, up-flow anaerobic sludge beds, and microbial fuel cells) biological treatments [1,15]; and (ii) other chemical, physical, and biological systems [16,17]. However, these treatments generally present a low efficiency, high costs, and process instability, mainly due to the high concentration of organic matter $(\mathrm{OM})$ and toxic compounds, such as ammonia nitrogen, in SW [5,9].

Natural systems, using lagoons or constructed wetlands, may be effective for SW treatment, due to the easy construction and cheap maintenance and operation [18-20], as well as the efficiency of removing several contaminants, such as OM; nutrients; heavy metals; and pathogens [16,21,22]. In general, SW is treated in anaerobic lagoons to remove $\mathrm{OM}$, while constructed wetlands are used for nutrient removal [23].

Constructed wetlands (CWs) have a low energy requirement and are compatible with typical farm operations [24]. These systems have been used for decades to treat municipal wastewater $[25,26]$, but their capacity to depurate agro-industrial wastewater and liquid livestock effluents have been recently demonstrated $[24,27,28]$. The results show that CW technology is established and its application for treating these effluents is well documented $[29,30]$. Regarding SW treatment, different successful experiences with CWs are reported in the literature, for both free water surface (FWS) and subsurface flow (SSF) types $[14,27,28,31]$. Most CWs treating SW are FWS systems, and only a few belong to SSF types [32-34]. Moreover, the interest in processes occurring in vertical SSF CWs is recent [35]. However, the COD concentrations in SW are commonly much higher than in municipal wastewater, and the nitrogen $(\mathrm{N})$ loads are always high $[10,36]$. Therefore, $\mathrm{CWs}$ of the SSF type have to be adapted to these high concentrations of livestock effluents [37].

CWs for livestock wastewater must always be coupled with pre-treatment strategies (e.g., filtration, lagooning, and anaerobic digestion), whose effectiveness is very important to the constructed wetlands' performance [23,37]. Before livestock effluents enter a CW, oxidation and settling treatments are required to remove much of the $\mathrm{OM}$, nitrogen, phosphorous loads, and suspended solids that can clog the soils in SSF systems [31]. Often, a pre-treatment using lagoons (to remove the COD and total suspended solids) may increase the depuration efficiency of CWs. For instance, an aerated lagoon can oxidize the organic load and convert $\mathrm{N}$ into a nitrate, and a non-aerated lagoon can increase the settlement of the suspended solids and the oxidation of OM without energy consumption $[38,39]$.

Some research experiences have evaluated the depuration performance of SW pretreatments before CWs. Sievers (1997) [40] examined two types of CWs, SSF and FWS, to treat effluents from an anaerobic swine lagoon system. Hunt et al. (2002) [27] investigated the effectiveness of CWs installed downstream of an anaerobic lagoon in a swine production facility. Shappell et al. (2007) [41] evaluated the effectiveness of a lagoon-CW combined treatment on SW, for producing an effluent with a low hormonal activity. Villamar et al. (2015) [23] studied the N and phosphorus distribution in a CW fed with SW previously treated in an anaerobic lagoon.

An examination of the $\mathrm{N}$ content of SW shows that concentrations between 0.2 and $0.4 \mathrm{~g} / \mathrm{L}$ of ammonium-N generate phyto-toxic effects on the vegetation of CWs (growth inhibition and biomass production) [7,42]. With wetland emergent plant species (such as, Glyceria, Carex, Typha, Schoenoplectus/Scirpus, and Juncus), the tolerance limit can be even lower $(<0.1 \mathrm{~g} / \mathrm{L})[43,44]$. The most effective process for $\mathrm{N}$ removal in CWs is nitrification/denitrification [7], because it converts ammonia predominantly to nitrogen [28]. Since nitrification limits the removal of $\mathrm{N}$ from animal wastewater, the enhancement of denitrification is expected to increase the efficiency of CW performance [28,45].

The most common method for enhancing denitrification is wastewater recirculation and the addition of partially-nitrified water [12,45]. It has been demonstrated that the recirculation of partially treated wastewater increases the total $\mathrm{N}$ removal in CWs from $70 \%$ to $85 \%$ [46], while water addition from a nitrifying lagoon leads to 4 - to 5 -fold $\mathrm{N}$ removal rates, compared to non-nitrified wastewater $[12,47]$. Moreover, effluent recirculation supplies wastewater with additional oxygen for aerobic microbial activities and a microbial 
biomass that is already adapted to noticeable $\mathrm{N}$ levels. The availability of oxygen and microbial mass in the $\mathrm{CW}$ is often a factor limiting the removal rates of organic and $\mathrm{N}$ loads from wastewater [34]. However, there is little research about the $\mathrm{N}$ removal in CWs for the treatment of SW [7]. Moreover, to the best of the authors' knowledge, no studies are available in literature about the combination of CW-lagoon processes and effluent recirculation in the case of SW. This leaves the depuration efficiency and usability of these methods not well understood, to date.

This study aims to address these gaps in the literature, by evaluating the depuration efficiency of a combined system consisting of lagoons (aerated and non-aerated tanks) and CWs (with Typha latifolia L.) working at pilot scale for treating SW under two recirculation rates (RRs) of the CW effluent. The specific aims of the research are: (i) evaluating the OM (measuring COD) and nitrogen removal rates of the system; (ii) assessing which of the two tested recirculation ratios are more effective; and (iii) identifying any phyto-toxic effects of the treated SW. The results of this study, if validated in similar environmental contexts, can contribute to a broader applicability of the studied depuration system, supporting the action of breeders to control the soil and water contamination by OM and nutrients in areas with a high pollution risk.

\section{Materials and Methods}

\subsection{Description of the Experimental System}

The present study was carried out in a swine breeding farm (geographical coordinates: $38^{\circ} 06^{\prime} 00^{\prime \prime} \mathrm{N}, 15^{\circ} 46^{\prime} 47^{\prime \prime} \mathrm{E}$ ) in Cardeto (Calabria, Southern Italy) at $1100 \mathrm{~m}$ a.s.l. The climate of the area is semi-arid and belongs to the "Csb" class ("Temperate, dry summer, warm summer Mediterranean" climate), according to Koppen, ref. [48] with cold winters and temperate summers. The mean annual temperature and precipitation were $11.1^{\circ} \mathrm{C}(\max$ $14.6^{\circ} \mathrm{C}$ and $\min 5.4^{\circ} \mathrm{C}$ ) and $1380 \mathrm{~mm}$, respectively (data obtained from the weather station of Gambarie, close to Cardeto).

The farm breeds approximately 1000 animals, and its SW is stored in a $180 \mathrm{~m}^{3}$ open pond. The pond is filled each day after stable cleaning and emptied about once a year.

The experimental pilot plant, which was installed over a flat area close to the pond, was a combination of lagoons and CW systems with two hydraulically independent treatment lines, both fed by the SW previously stored in the pond. The system operated as a batch treatment. The lagoon system of each treatment line consisted of a series of two $1000 \mathrm{~L}$ tanks, supplied with $40 \mathrm{~L} / \mathrm{d}$ of SW. One tank was aerated (with an air flow rate of $75 \mathrm{~L} / \mathrm{h}$ ) by a fine bubble diffuser placed $5 \mathrm{~cm}$ above the tank bottom and fed by a blower. The second tank was not aerated (Figure 1). Both tanks were occasionally covered against precipitation, but the cap allowed air entry from the water surface.

The aeration system was the same as the device described by $[38,39,49]$, in which more details can be found. Downstream of the two tanks, a third smaller tank (which was not aerated) allowed SW storage before the subsequent treatment. This tank acted as a hydraulic disconnection between the two systems (lagoon and CW). Each tank was intermittently supplied with 20 and $50 \mathrm{~L} / \mathrm{h}$ of SW in eight cycles per day.

The effluent of the disconnecting tank was transferred into the CW (with a volume of $1.6 \mathrm{~m}^{3}$ and a size of $2 \mathrm{~m} \times 1 \mathrm{~m} \times 0.80 \mathrm{~m}$ ) made of LDPE. The CW system was a V-SSF type, with a distributor uniformly spreading water over the soil surface. This type of CW was chosen due to its higher capacity to transport oxygen, compared to CWs with a horizontal flow. Therefore, V-SSF CWs are more efficient in removing OM and ammonia-N from wastewater through the aerobic microbial activity [34]. The CW was filled with two layers of soil (with a total depth of $0.6 \mathrm{~m}$ ), of which the upper layer $(0.4 \mathrm{~m})$ was a loamy texture, and the bottom layer $(0.2 \mathrm{~m})$ was composed of gravel (diameter 5-20 mm). The upper layer was mixed with sand (sand/soil ratio $=3: 1$ ) to increase the porosity $(35 \%)$ and thus the infiltration of SW. 


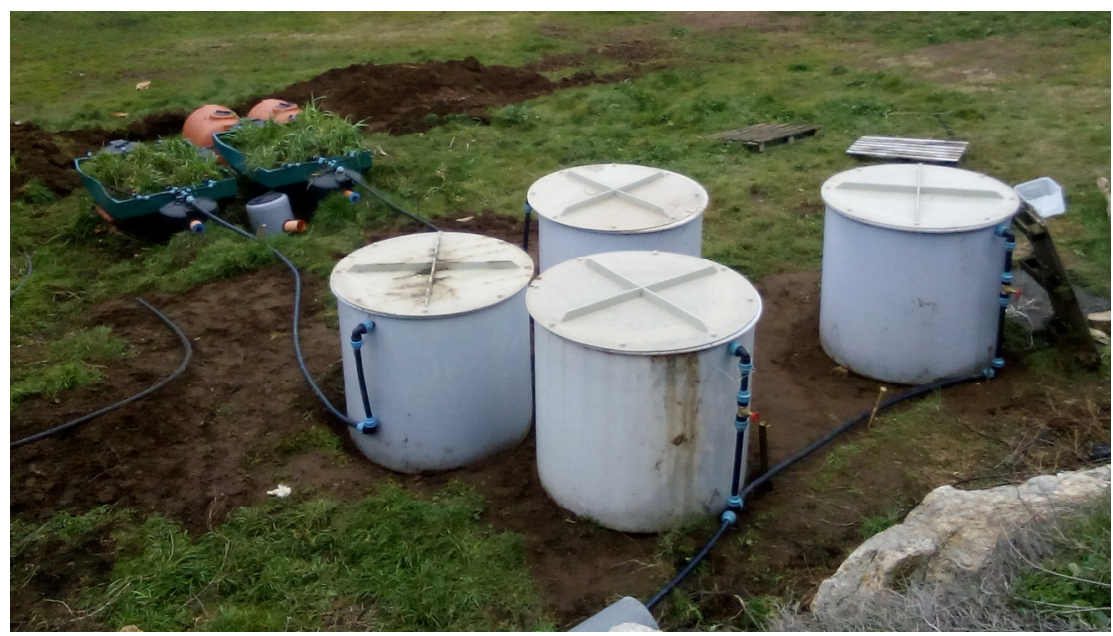

(a)

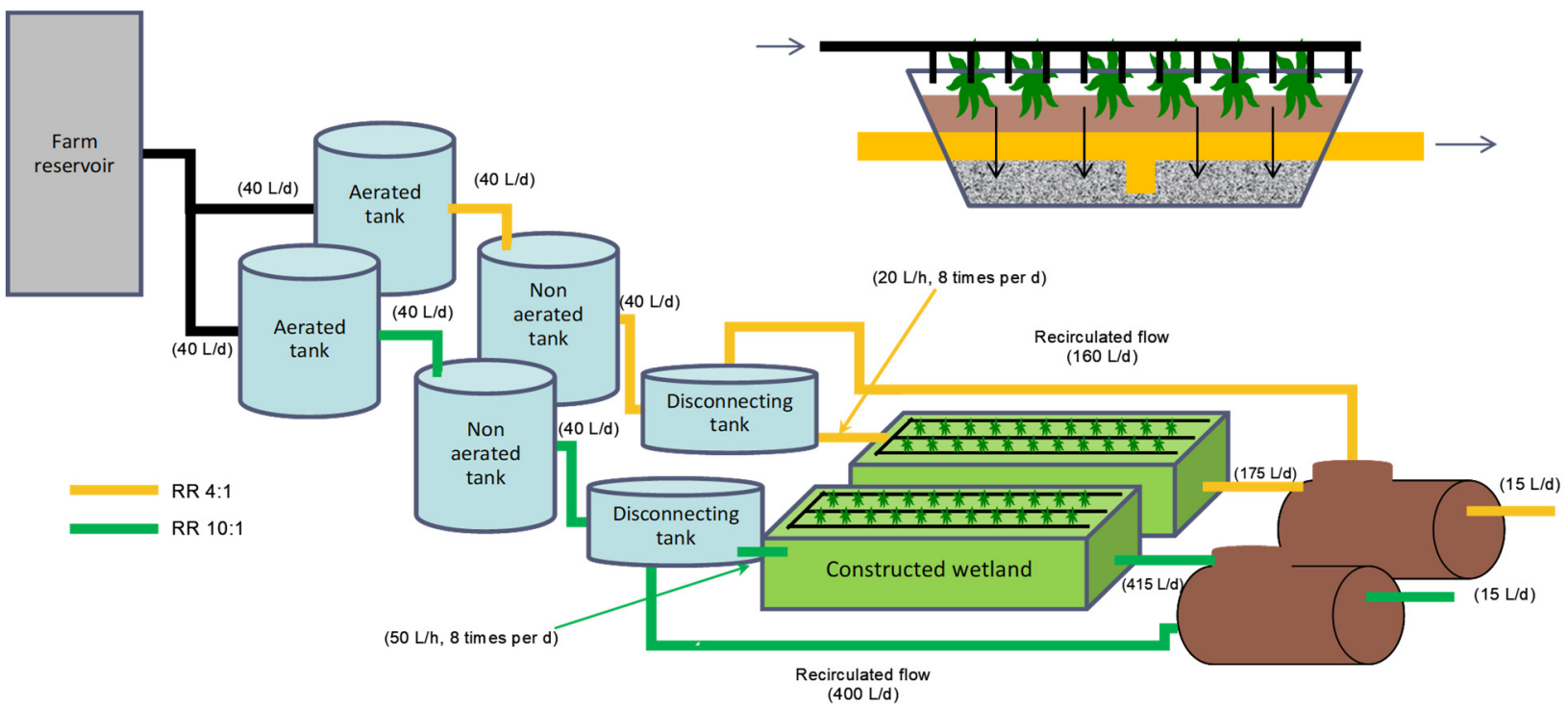

(b)

Figure 1. Photo (a) and scheme (b) of the lagoon-CW integrated system for treating swine wastewater in the experimental plant with the input/output water flow rates displayed.

The soil in the CW was planted with cattail (Typha latifolia L., 6 plants $/ \mathrm{m}^{2}$ ) in March 2017. This species is one of the most commonly used macrophytes in CWs beside bulrush (Scirpus spp.) and common reed (Phragmites australis), especially in the case of livestock water treatment $[12,24]$.

A by-pass pipeline permitted the recirculation of the effluent in the system. More specifically, the effluent was pumped from the final tank into the disconnection tank. Two RRs were tested, one for each treatment line (Figure 1). The first RR was 4:1 (recirculated water:influent of the CW); the second was 10:1; and 160 and $400 \mathrm{~L} / \mathrm{h}$ of SW were recirculated in the two lines, respectively. These ratios were selected setting up the theoretical total nitrogen $(\mathrm{TN})$ concentration of the influent to about $0.2(\mathrm{RR}=10: 1)$ and $0.5(\mathrm{RR}=4: 1) \mathrm{g} / \mathrm{L}$, close to the tolerance limits reported by $[7,42]$. The hydraulic loads were 220 and $100 \mathrm{~L} / \mathrm{d} / \mathrm{m}^{2}$ for RRs 10:1 and 4:1, respectively.

A final tank receiving the effluent was located downstream of each CW. About $15 \mathrm{~L} / \mathrm{d}$ was collected in this tank for both treatment lines (Figure 1).

The volume of SW to irrigate the plants in the CW was set according to the water requirement, due to the evapo-transpiration (ET) rate of the cattail. Therefore, the ET was monitored every week, measuring a third CW the water losses. 


\subsection{Wastewater Sampling and Characterization}

Samples of SW were collected twice a month between March 2017 and March 2019, and immediately stored at $4{ }^{\circ} \mathrm{C}$ until the laboratory analysis.

The SW samples were collected: (i) in the farm storage pond (influent of the lagoon system); (ii) in the disconnection tank (effluent of lagoon system and influent of the CW), before the water flow mixing for recirculation; and (iii) in the final tank (effluent of CW).

The following characteristics were evaluated in the SW samples: the $\mathrm{pH}$ and electrical conductivity (EC), using a Hach Lange HQ40 multi-parameter device with dedicated probes, and the total suspended solids (TSS), after oven-drying at $105^{\circ} \mathrm{C}$ for $24 \mathrm{~h}$. Moreover, according to the standard methods [50], the chemical oxygen demand (COD) and total Kjeldahl nitrogen (TKN, the sum of organic nitrogen, un-ionized ammonia, and ammonium ion) were determined. The initial values of these SW parameters measured in the farm reservoir are reported in Table 1.

Table 1. Main parameters of swine wastewater initially sampled in the storage tank of the swine breeding farm.

\begin{tabular}{cc}
\hline Parameter & $\begin{array}{c}\text { Value } \\
\text { (mean } \pm \text { std. dev., } \boldsymbol{n = 3} \text { ) }\end{array}$ \\
\hline $\mathrm{pH}[-]$ & $7.40 \pm 0.0$ \\
TS [\%] & $0.96 \pm 0.0$ \\
COD [g L & $29.3 \pm 1.01$ \\
TKN [g L $\left.{ }^{-1}\right]$ & $1.29 \pm 0.44$ \\
\hline
\end{tabular}

Notes: TS = total solids; $\mathrm{COD}=$ chemical oxygen demand; and TKN = total Kjeldahl nitrogen.

\subsection{Statistical Analyses}

The statistical significance of differences in the main parameters of SW (farm reservoir vs. lagoon effluent vs. $C W$ at $R R=4: 1$ vs. $C W$ at $R R=10: 1)$ and plant density in CWs (at $R R=4: 1$ vs. $R R=10: 1$ ) was evaluated using Kruskal-Wallis tests (a non-parametric alternative to the analysis of variance), followed by multiple pairwise comparisons using Dunn's procedure with the Bonferroni correction for the significance level for the pairwise comparisons. To differentiate the levels of significance, a $p$-level lower than 0.05 was adopted.

\section{Results and Discussions}

\subsection{Depuration Performance of the Lagoon System}

The lagoons decreased the $\mathrm{pH}$ (in the range of 7.48-7.86, farm reservoir, and 6.70-8.32, effluent) and EC from the influent (13.1-21.4 dS/m) to the effluent (6.09-19.7 dS/m). This parameter showed a noticeable temporal variability both in the influent and effluent. The TSS concentration decreased from values of up to $19-20 \mathrm{~g} / \mathrm{L}$ measured in the farm reservoir (with a noticeable decreasing trend over time) to $0.34-1.43 \mathrm{~g} / \mathrm{L}$ in the effluent (Figure 2).

After the lagoon, the COD concentration of the influent (generally with a limited temporal variability, 36.1 to $49.3 \mathrm{~g} / \mathrm{L}$ ) reduced, and the removal rate increased over time. The COD concentration in the effluent was between 8.56 and $36.3 \mathrm{~g} / \mathrm{L}$. The TKN decreased over time in the farm reservoir (from 1.26 to $2.60 \mathrm{~g} / \mathrm{L}$ ), but for this parameter the removal rate showed a low variability, reducing the $\mathrm{N}$ concentration from 1.04 to $1.84 \mathrm{~g} / \mathrm{L}$ (Figure 2). 


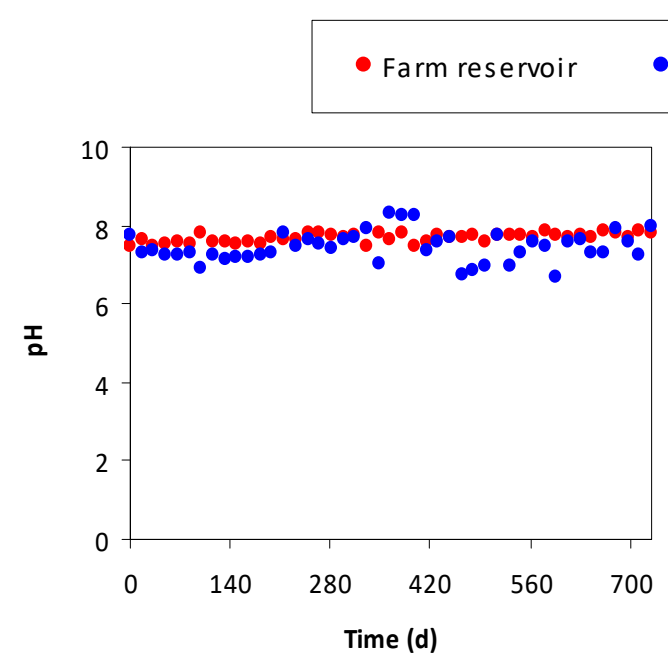

Lagoon treatment effluent
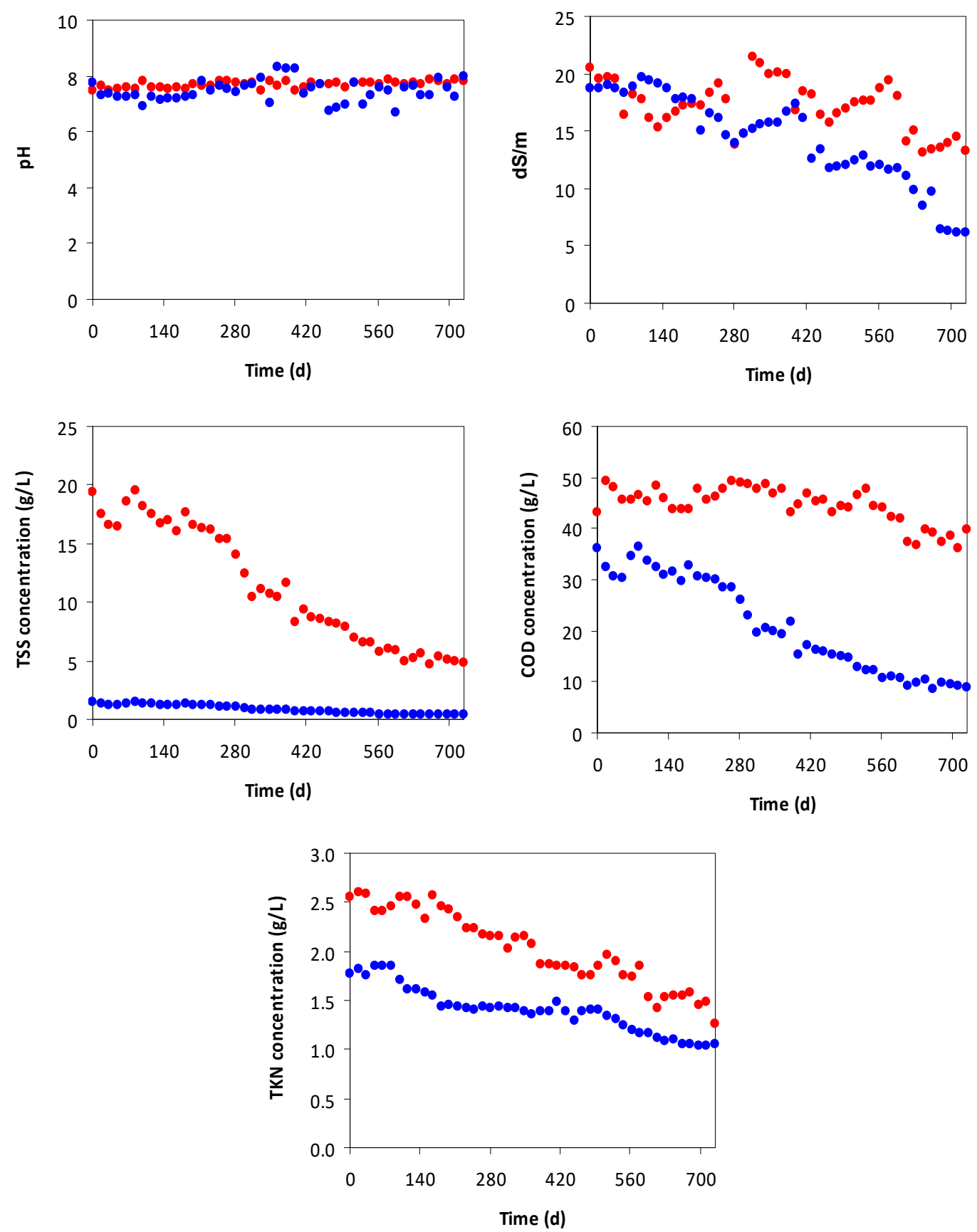

Figure 2. Variation of the main parameters over time of the lagoons of the integrated system for swine wastewater treatment (the reported values are averaged between the two lines of the lagoon system).

\subsection{Depuration Performance of the Constructed Wetland}

The SW treatment in CWs reduced the $\mathrm{pH}$ without significant differences between the tested RRs. This parameter was in the range of $6.0-8.0$ for both RRs. However, the $\mathrm{pH}$ fluctuated in this range, according to the weather variations (Figure 3).

The EC declined in the CW under both RRs with a more noticeable effect (significant at $p<0.05$ ) at the lower ratio (from 3.48 to $2.41 \mathrm{dS} / \mathrm{m}, \mathrm{RR}=4: 1$, and from 2.83 to $0.96 \mathrm{dS} / \mathrm{m}$, $\mathrm{RR}=10: 1$ (Figure 3). 
The TSS concentration decreased (from 88.2 to $54.2 \mathrm{mg} / \mathrm{L}, \mathrm{RR}=4: 1$, and from 41.3 to $25.2 \mathrm{mg} / \mathrm{L}, \mathrm{RR}=10: 1$ ) for both RRs, following similar temporal trends (Figure 3), although the differences were significant. In contrast, the removal rates of both COD and TKN were significantly much higher in the CW, with an RR of 4:1. The higher RR reduced the COD from 98.2 to $40.3 \mathrm{mg} / \mathrm{L}$ in the CW with an RR of 4:1, and from 39.33 to $20.84 \mathrm{mg} / \mathrm{L}$ with an RR of 10:1. This difference was also detected for TKN, which decreased from 668 to 379 $\mathrm{mg} / \mathrm{L}(\mathrm{RR}=4: 1)$ and from 176 to $108 \mathrm{mg} / \mathrm{L}(\mathrm{RR}=10: 1)$ (Figure 3).
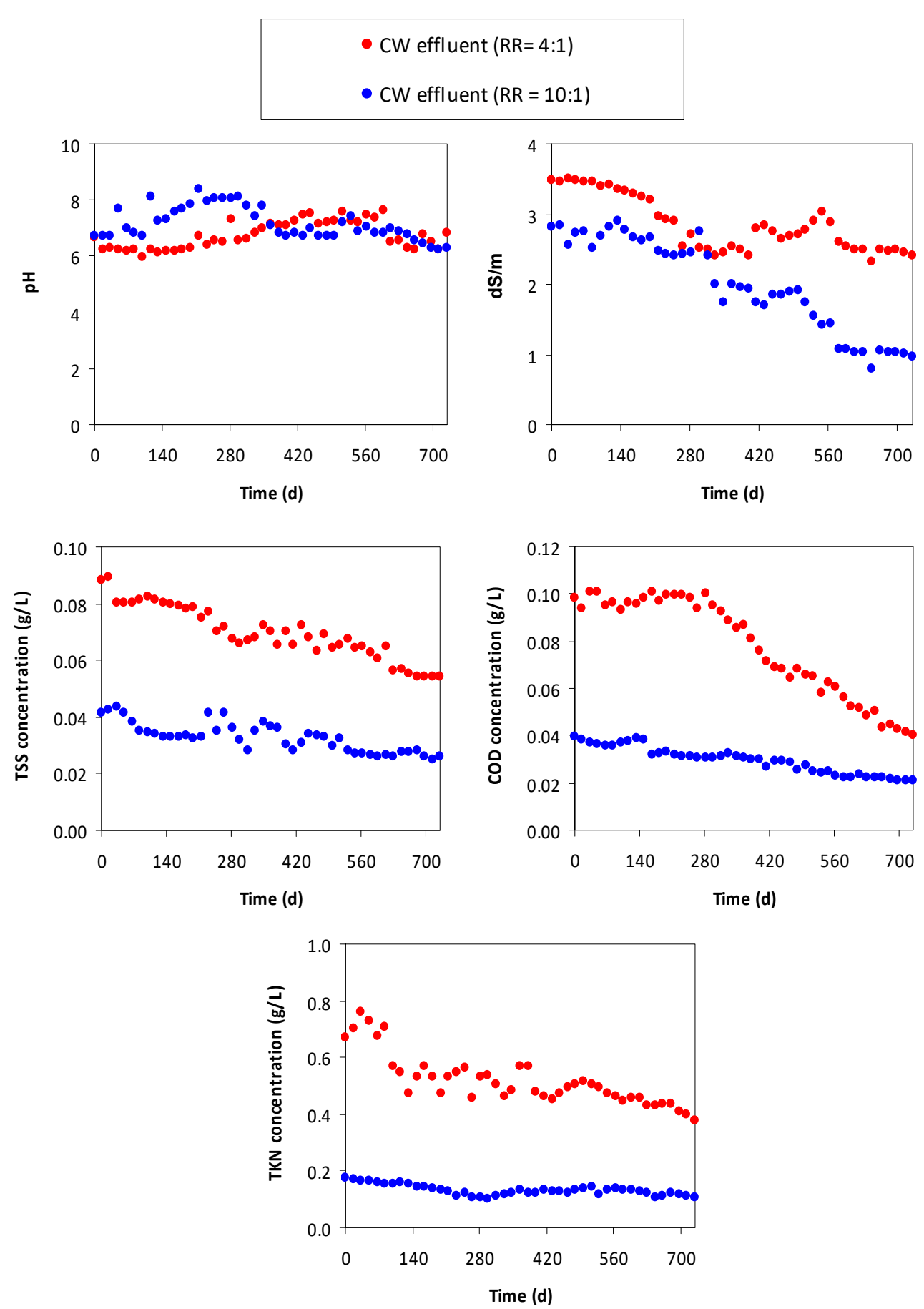

Figure 3. Variation of the main parameters over time of the constructed wetlands (at two recirculation ratios, RR) of the integrated system for swine wastewater treatment. 


\subsection{Variations in SW Parameters and the Removal of Pollutants}

A separate analysis of the variability in the monitored parameters of SW in the two treatments (lagoon or $\mathrm{CW}$ ) shows: (i) for the $\mathrm{pH}$, slight variations in the lagoon system (by $-1.89 \pm 4.17 \%$ ) and a greater decrease in the CW (on average 10-13\%); (ii) a limited reduction in EC in the lagoon system $(-4.76 \pm 14.8 \%)$, and a much greater decrease in the CW system ( -84.0 to $-89.0 \%, R R=4: 1$ and $10: 1$, respectively); (iii) an appreciable removal of TSS in the lagoon system $(42.4 \pm 35.3 \%)$ and a very high effectiveness in the CW (close to $100 \%$ ); (iv) a limited efficiency in COD removal in the lagoon system $(2.17 \pm 4.88 \%)$, and, in contrast, an extremely high removal in the CW (also, in this case, close to $100 \%$ ); and (v) a TKN removal by $31.0 \pm 15.6 \%$ in the lagoon system, which increases to $72.7 \pm 2.48 \%$ $(\mathrm{RR}=4: 1)$ and to $92.7 \pm 1.13 \%(\mathrm{RR}=10: 1)$ in the $\mathrm{CW}$ (Figure 4$)$.

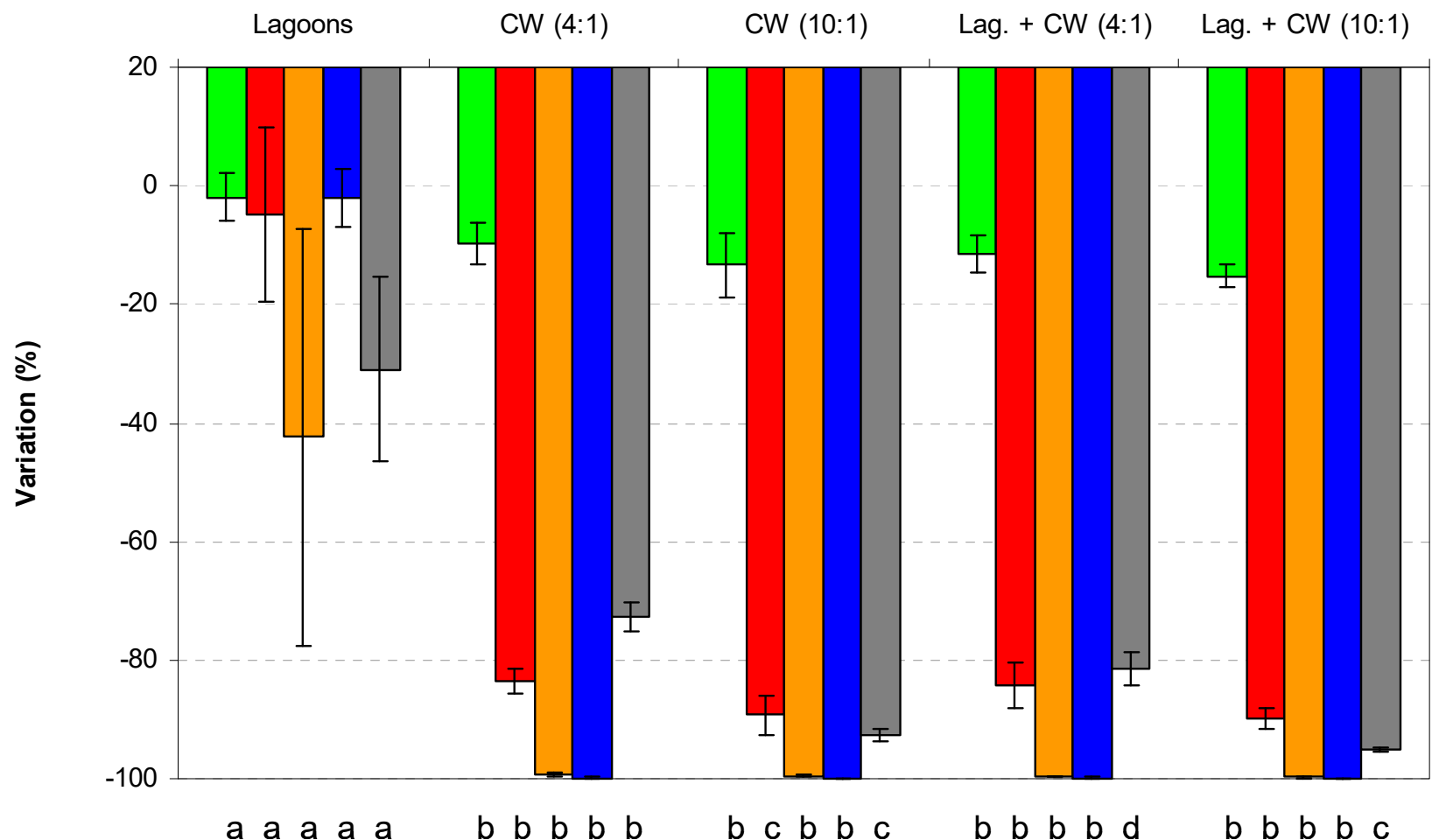

Figure 4. Variation (mean \pm standard deviation) of the main parameters in the combined system using lagoons and constructed wetlands (CW, at two recirculation ratios (RR)) for swine wastewater treatment. Standard deviation is related to the parameter variability among the three survey dates (March 2017, 2018, and 2019). Letters indicate significant differences among the treatments (at $p<0.05$ ).

If this analysis is carried out for the combined system (lagoon $+\mathrm{CW}$ under the two RRs), the following considerations can be derived: (i) the two RRs show a comparable effectiveness for $\mathrm{pH}$ modification $(-11.4 \pm 3.24 \%$, $\mathrm{RR}=4: 1$, to $-15.2 \pm 1.83 \%$, RR $=$ 10:1); (ii) a higher RR is more efficient to reduce the EC of SW $(-90 \pm 1.73 \%, R R=10: 1$, against $-84.2 \pm 3.92 \%$, $R R=4: 1$ ); (iii) both RRs provide an extremely high efficiency in removing TSS and COD (close to 100\%); (iv) the efficiency in TKN removal increases from $81.4 \pm 2.74 \%$ to $95.1 \pm 0.45 \%$, when the RR is increased from $4: 1$ to $10: 1$ (Figure 4 ).

\subsection{Effects of COD and TKN on Typha latifolia L. Plants}

Compared to the initial density (6 plants $\left./ \mathrm{m}^{2}\right)$, no significant effects of SW supply were noticed in the survival rates of Typha latifolia L. in CWs in the dry seasons (spring and summer, $18.5 \pm 1.1^{\circ} \mathrm{C}$ ) (Figure 5). In fact, no death of plants was recorded in the $\mathrm{CW}$ under $R R=10: 1$, except 0.5 plants $/ \mathrm{m}^{2}$ in the summer of 2018. In the CW under the lower RR, the plant mortality was slightly higher in summer (especially in $2018,1.4$ plants $/ \mathrm{m}^{2}$ ). This plant death can be attributed to a peak in the soil N, presumably due to the excessive load 
of the influent (0.5-0.7 g/L) from the spring to winter seasons in 2017 (data not shown). The TKN concentrations of about $0.14-0.16 \mathrm{~g} / \mathrm{L}$ in the $\mathrm{CW}$ with $\mathrm{RR}=10: 1$ were, instead, well tolerated by the plants.

Several plants died in the cold seasons (autumn and winter), due to vegetative senescence. This plant death was particularly high in the season 2017-2018, when an extreme frost occurred in December. After this event, the killed plants were replaced by new plants, to restore the initial plant density.

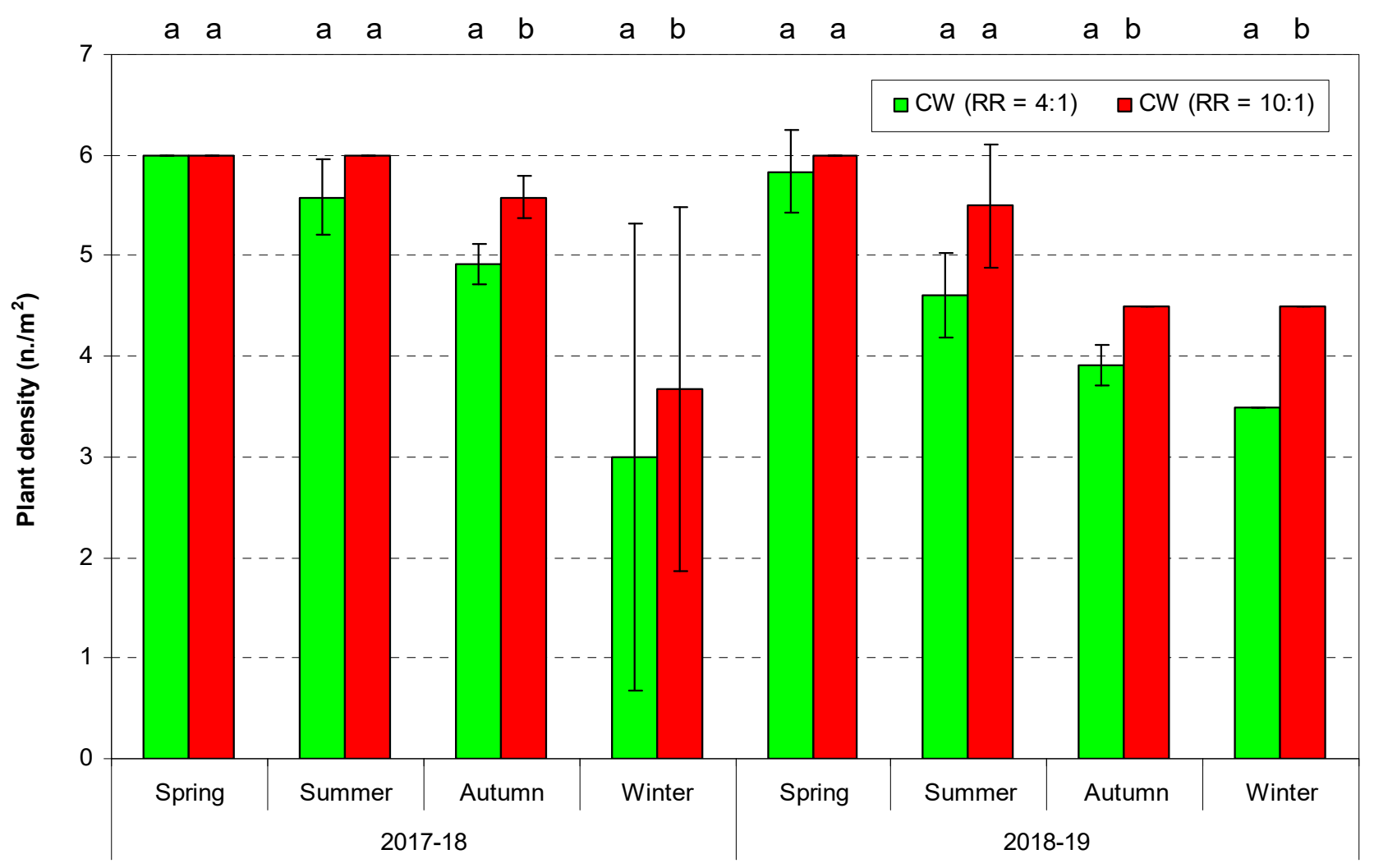

Figure 5. Plant density (mean \pm standard deviation among the months) surveyed over two seasons in the constructed wetlands $(\mathrm{CW}$, at two recirculation ratios, $(\mathrm{RR}))$ of the integrated system for swine wastewater treatment. Letters indicate significant differences between the treatments with different $\mathrm{RR}$ (at $p<0.05)$.

\section{Discussions}

The evaluation of the main chemical properties of the SW treated in the combined system using lagoons and constructed wetlands has produced important indications in terms of depuration efficiency and, therefore, of its sustainability.

Concerning the depuration performance of the lagoon system, the decrease in the TSS concentration due to the lagoon process is well known [51]. The presence of a nonaerated tank promoted the activity of anaerobic bacteria, which degraded the organic matter concentration, and this also reduced the amount of the TSS [49,52,53]. Furthermore, the effect of aeration in the upstream tank promoted the flocculation process, due to the accelerated bacterial activity [52].

Although the reductions in the amounts of the OM and TKN, as a result of the lagoon system, were noticeable, the concentrations in the effluent noticeably exceeded the accepted amount for the discharge limits permitted by the main national rules. For example, according to the Italian environmental regulation (Legislative Decree 152 of 2006), the concentrations of nutrients and OM were about two orders of magnitude for the limits, equal to $20 \mathrm{mg} / \mathrm{L}$ for $\mathrm{N}$ and $160 \mathrm{mg} / \mathrm{L}$ for COD.

Concerning the depuration performance of the constructed wetland, the reduction in the $\mathrm{pH}$ of SW, which was close to neutrality, was in accordance with Boas et al. (2018) [54], 
who worked on CWs combining H-SSF and V-SSF systems, which favor the microbial activity of $\mathrm{OM}$ degradation and nutrient conversion.

The noticeable decline detected in the TSS concentration for both RRs is expected, since TSS is the water parameter that is strongly modified by CW treatments, as a consequence of the sedimentation, filtration, and adsorption processes that occur in CWs [33].

The COD and TKN removal in the CW were high, presumably due to the synergistic effects of both physical, chemical, and microbial processes, also under heavy loads of OM and nutrients, as is presented in this study. Organic and $\mathrm{N}$ compounds are removed in CWs of the SSF type by a combination of adsorption, nitrification/denitrification, volatilization, and ionic exchange [3]. Nitrification and denitrification are considered essential mechanisms for $\mathrm{N}$ removal [1,37], having an efficiency of more than $60 \%$ [55]. According to Vidal et al. (2018) [3], denitrification is the most effective process to remove nitrogen in CWs, and the aerated and non-aerated treatments prior to $\mathrm{CW}$ in the experimental plant have been beneficial for these processes. The aerated treatment has oxidized part of the TKN in SW, which was converted to nitrate. The aerated treatment should have denitrified part of this nitrate, but the remaining part was made available for denitrification in $\mathrm{CW}$, which is nitrate-limited [3,27]. The nitrification of SW before the $\mathrm{CW}$ enhances $\mathrm{N}$ removal, and increases the nitrate available for denitrification [45]. Moreover, the absence of aeration should have provided anaerobic bacteria that were already adapted to the denitrification process. Denitrification is more desirable than ammonia volatilization in CWs treating the wastewater of animal origin, since ammonia is a pollutant for atmospheric, aquatic, and terrestrial environments through dry and wet deposition [45]. In our study, although not being directly measured, ammonia volatilization may have been limited, due to the $\mathrm{pH}$ level that was lower than eight $[1,56,57]$, while the nitrification process should have been presumably low, due to the limited oxygen supply from the plants. Therefore, denitrification may have been the dominant process in TKN removal, in close accordance with Hunt et al. (2002) [27]. An important role in nutrient and OM removal is played by bacteria, which create a biofilm around the soil particles, allowing the catalysis of chemical reactions [33]. Effluent recirculation enabled the wastewater to flow repeatedly over this biofilm, enhancing the contact between the pollutants and microorganisms [33,34].

Plant uptake helps nitrogen removal, but its influence is lower compared to the other processes, and depends on the specific species. Plants remove ammonia nitrogen due to the stimulation of nitrifying bacteria and the uptake of nitrogen compounds [8], but these mechanisms seem to be marginal in many examples. Typha latifolia L. prefers slightly acidic environments, but ammonium uptake is conditioned by its toxicity ( $>0.2 \mathrm{~g} / \mathrm{L})$ [23] and COD concentrations of $0.6-0.8 \mathrm{~g} / \mathrm{L}$ (that inhibit photo-synthesis and, consequently, nutrient incorporation) $[23,58]$, as was evident in many stages of our study. Gonzales et al. (2009) [36] stated that the macrophyte species did not significantly contribute to the overall efficiency of V-SSF CWs in N removal, especially in the dry season. These authors attributed this minor contribution of plants to the high concentrations of contaminants. In contrast, planted CWs clearly show higher efficiencies for organic compounds, with removal efficiencies of up to $70 \%$ in wetlands planted with Typha latifolia L. compared to $60 \%$ of unplanted beds [36].

In relation to the variations in SW parameters and the removal of pollutants, the present study has demonstrated that the CW was more efficient in removing TSS, COD, and TKN compared to the lagoon. The lower efficiency for TSS removal in the lagoon system compared to the $\mathrm{CW}$ can be attributed to the great solid content of the raw SW. This low efficiency is close to the value of $25 \%$ experienced by Stone et al. (2004) [59] for SW lagoon treatment in North Carolina. To increase the system ability to remove TSS, a pre-treatment to remove further amounts of TSS in the raw SW is still necessary because it can prevent the soils of $\mathrm{CW}$ from being rapidly clogged. The very high efficiencies of the CW system in removing TSS are in close accordance with the values (97-99\%) reported by $[14,33]$. In the experiences of other authors, TSS removal efficiencies between $40-50 \%$ [3] and $70-80 \%[35,36]$ were detected. Literature reports COD removal efficiencies in the range 
of $50-80 \%$ [33,35,36,60] with an extreme value of 99.5\% detected by Masi et al. (2017) [14] working in a CW combined system (as in our study). $\mathrm{N}$ removal varies between $60 \%$ and $80 \%$ according to many authors $[3,8,11,27,36,54]$, but extreme values are also reported $(10-40 \%[33,35]$ to $99 \%$ [14]). In our study, the TKN removal efficiency for the CW system with $\mathrm{RR}=4: 1$ is in the range reported by the majority of studies, and it is not far from the optimal value of [14] in the CW with $R R=10: 1$.

The analysis of the depuration efficiency of the combined system (lagoon + CW under the two RRs) suggests the adoption of an RR equal to 10:1, in order to increase the TKN removal, while the efficiency of reducing the $\mathrm{pH}$ and $\mathrm{EC}$, and removing the TSS and COD, is comparable. Similar to the observations of Lee et al. (2006) and He et al. (2004) [33,34], the effluent recirculation in the system supplies a considerable amount of oxygen in the SW, promoting the reductions in COD and TKN. Concerning the experiences using V-SSFCWs systems with recirculation, He et al. (2006) [34] showed that this operation strategy increased the average removal efficiencies of $\mathrm{NH}_{4}-\mathrm{N}, \mathrm{COD}$, and TSS to $62 \%, 81 \%$, and $77 \%$, respectively, compared to the values of $36 \%, 50 \%$ and $49 \%$, without effluent recirculation. With an RR of $100 \%$, the average removal efficiencies were $91 \%$ for COD and $96 \%$ for TSS [61].

Regarding the effects of COD and TKN on Typha latifolia L., the irrigation of the CW with SW effluents from the lagoon treatment did not affect plant survival in the dry season, especially at the higher RR. In contrast, the higher plant mortality detected in the CW with the lower RR can be attributed to a peak in the nitrogen load, which exceeded the tolerance limits of Typha latifolia L. These limits were quantified by De los Reyes et al. (2014) [7] between 0.2 and $0.4 \mathrm{~g} / \mathrm{L}_{\text {of }} \mathrm{NH}_{4}{ }^{+}-\mathrm{N}$, which correspond to $60-80 \%$ of TKN, and therefore the expected phyto-toxic effects may have been realistic.

\section{Conclusions}

This study has shown that a pilot-scale system consisting of open lagoons (with or without aeration) and a constructed wetland with Typha latifolia L. treating raw swine wastewater has removed about $99 \%$ of the total suspended solids and COD, and from $80 \%$ to $95 \%$ of the total nitrogen in the effluent at both tested recirculation rates $(4: 1$ and 10:1). Both the $\mathrm{pH}$ and the electrical conductivity (the indirect measure of wastewater salinity) were noticeably modified by the combined system, and reductions in the electrical conductivity (85-90\%) were detected. The lagoon system alone showed low to moderate depuration performances $(-40 \%$ of TSS, $-2 \%$ of COD, and $-31 \%$ of TKN removed), but represented an effective pre-treatment of $\mathrm{CW}$, particularly for the nitrogen removal.

This experience has also demonstrated the suitability to increase the effluent recirculation ratio up to a value of 10:1, when high nitrogen removal rates are expected, since the higher RR allowed the removal of about $20 \%$ more of nitrogen compounds compared to an $R R$ of $4: 1$. In contrast, the organic matter removal was not affected by an increased RR, given the very high depuration efficiency detected at the lower RR.

The irrigation of the CWs with SW did not generally determine the phyto-toxic effects on Typha latifolia L., except at the start of the experiment and under the lower effluent recirculation ratio, when a peak in the soil nitrogen killed about $25 \%$ of plants.

Although this study was carried out on pilot plants and throughout a short monitoring period (two years), the relevant results provide a starting point for the use of V-SSF CWs as a depuration solution in highly polluting livestock wastewater (such as, SW). An upscale of this preliminary investigation is suggested to verify the depuration performance of the system by real-scale experiments. A more detailed analysis of the physico-chemical and microbiological processes acting in the CW system may help to identify the most effective mechanisms for removing the polluting compounds of SW. Moreover, the incidence of each process that determines a mass loss (e.g., volatilization, denitrification, nitrogen plant uptake, and hydraulic losses) on water, soil, and plants of each sub-component of the experimental system should be quantified adopting a mass balance approach in future research. 
Author Contributions: Conceptualization, G.B., D.A.Z. and S.M.Z.; methodology, N.B., G.B., P.D., A.F. and D.A.Z.; validation, G.B., D.A.Z. and S.M.Z.; formal analysis, G.B., P.D., A.F., D.A.Z. and S.M.Z.; data curation, N.B., G.B., P.D., A.F. and D.A.Z.; writing-original draft preparation, P.D. and D.A.Z.; writing-review and editing, G.B., P.D., D.A.Z. and S.M.Z.; supervision, G.B., D.A.Z. and S.M.Z.; project administration, S.M.Z.; funding acquisition, S.M.Z. All authors have read and agreed to the published version of the manuscript.

Funding: This research was funded by the National Project "PRIN-Programmi di Ricerca di Interesse Nazionale" (2015), by the Italian Ministry of Education, University and Research (M.I.U.R., Principal Investigator Attilio Toscano).

Institutional Review Board Statement: Not applicable.

Informed Consent Statement: Not applicable.

Data Availability Statement: The data presented in this study are available on request from the corresponding author.

Acknowledgments: We cordially thank the "Società Agricola Biondo dei F.lli Biondo \& C." firm (Cardeto, Reggio Calabria, Italy) for hosting the experimental device and providing the manpower for its management.

Conflicts of Interest: The authors declare no conflict of interest.

\section{References}

1. Hu, H.; Li, X.; Wu, S.; Yang, C. Sustainable Livestock Wastewater Treatment via Phytoremediation: Current Status and Future Perspectives. Bioresour. Technol. 2020, 315, 123809. [CrossRef] [PubMed]

2. Algieri, A.; Andiloro, S.; Tamburino, V.; Zema, D.A. The Potential of Agricultural Residues for Energy Production in Calabria (Southern Italy). Renew. Sustain. Energy Rev. 2019, 104, 1-14. [CrossRef]

3. Vidal, G.; de Los Reyes, C.P.; Sáez, O. The Performance of Constructed Wetlands for Treating Swine Wastewater under Different Operating Conditions. In Constructed Wetlands for Industrial Wastewater Treatment; Alexandros, S., Ed.; John Wiley \& Sons, Ltd.: Chichester, UK, 2018; pp. 203-221. ISBN 978-1-119-26837-6.

4. Cheng, D.L.; Ngo, H.H.; Guo, W.S.; Liu, Y.W.; Zhou, J.L.; Chang, S.W.; Nguyen, D.D.; Bui, X.T.; Zhang, X.B. Bioprocessing for Elimination Antibiotics and Hormones from Swine Wastewater. Sci. Total Environ. 2018, 621, 1664-1682. [CrossRef] [PubMed]

5. Folino, A.; Calabrò, P.S.; Zema, D.A. Effects of Ammonia Stripping and Other Physico-Chemical Pretreatments on Anaerobic Digestion of Swine Wastewater. Energies 2020, 13, 3413. [CrossRef]

6. Viancelli, A.; Kunz, A.; Steinmetz, R.L.R.; Kich, J.D.; Souza, C.K.; Canal, C.W.; Coldebella, A.; Esteves, P.A.; Barardi, C.R.M. Performance of Two Swine Manure Treatment Systems on Chemical Composition and on the Reduction of Pathogens. Chemosphere 2013, 90, 1539-1544. [CrossRef] [PubMed]

7. De Los Reyes, C.P.; Pozo, G.; Vidal, G. Nitrogen Behavior in a Free Water Surface Constructed Wetland Used as Posttreatment for Anaerobically Treated Swine wastewater effluent. J. Environ. Sci. Health-Part A Toxic/Hazard. Subst. Environ. Eng. 2014, 49, 218-227. [CrossRef] [PubMed]

8. Dordio, A.; Carvalho, A.J.P. Constructed Wetlands with Light Expanded Clay Aggregates for Agricultural Wastewater Treatment. Sci. Total Environ. 2013, 463-464, 454-461. [CrossRef]

9. Folino, A.; Zema, D.A.; Calabrò, P.S. Environmental and Economic Sustainability of Swine Wastewater Treatments Using Ammonia Stripping and Anaerobic Digestion: A Short Review. Sustainability 2020, 12, 4971. [CrossRef]

10. Folino, A.; Zema, D.A.; Calabrò, P.S. Organic Matter Removal and Ammonia Recovery by Optimised Treatments of Swine Wastewater. J. Environ. Manag. 2020, 270, 110692. [CrossRef]

11. Tanner, C.C.; Clayton, J.S.; Upsdell, M.P. Effect of Loading Rate and Planting on Treatment of Dairy Farm Wastewaters in Constructed Wetlands-II. Removal of Nitrogen and Phosphorus. Water Res. 1995, 29, 27-34. [CrossRef]

12. Harrington, C.; Scholz, M. Assessment of Pre-Digested Piggery Wastewater Treatment Operations with Surface Flow Integrated Constructed Wetland Systems. Bioresour. Technol. 2010, 101, 7713-7723. [CrossRef]

13. Qian, X.; Wang, Z.; Shen, G.; Chen, X.; Tang, Z.; Guo, C.; Gu, H.; Fu, K. Heavy Metals Accumulation in Soil after 4 Years of Continuous Land Application of Swine Manure: A Field-Scale Monitoring and Modeling Estimation. Chemosphere 2018, 210, 1029-1034. [CrossRef]

14. Masi, F.; Rizzo, A.; Martinuzzi, N.; Wallace, S.D.; Van Oirschot, D.; Salazzari, P.; Meers, E.; Bresciani, R. Upflow Anaerobic Sludge Blanket and Aerated Constructed Wetlands for Swine Wastewater Treatment: A Pilot Study. Water Sci. Technol. 2017, 76, 68-78. [CrossRef] [PubMed]

15. Zema, D.A. Planning the Optimal Site, Size, and Feed of Biogas Plants in Agricultural Districts. Biofuels Bioprod. Bioref. 2017, 11, 454-471. [CrossRef]

16. Kim, J.-H.; Chen, M.; Kishida, N.; Sudo, R. Integrated Real-Time Control Strategy for Nitrogen Removal in Swine Wastewater Treatment Using Sequencing Batch Reactors. Water Res. 2004, 38, 3340-3348. [CrossRef] [PubMed] 
17. Mehta, C.M.; Khunjar, W.O.; Nguyen, V.; Tait, S.; Batstone, D.J. Technologies to Recover Nutrients from Waste Streams: A Critical Review. Crit. Rev. Environ. Sci. Technol. 2015, 45, 385-427. [CrossRef]

18. Hamza, R.A.; Iorhemen, O.T.; Tay, J.H. Anaerobic-Aerobic Granular System for High-Strength Wastewater Treatment in Lagoons. Adv. Environ. Res. 2016, 5, 169-178. [CrossRef]

19. Gikas, G.D.; Tsakmakis, I.D.; Tsihrintzis, V.A. Hybrid Natural Systems for Treatment of Olive Mill Wastewater. J. Chem. Technol. Biotechnol. 2018, 93, 800-809. [CrossRef]

20. Molari, G.; Milani, M.; Toscano, A.; Borin, M.; Taglioli, G.; Villani, G.; Zema, D.A. Energy Characterisation of Herbaceous Biomasses Irrigated with Marginal Waters. Biomass Bioenergy 2014, 70, 392-399. [CrossRef]

21. Pishgar, R.; Hamza, R.A.; Tay, J.H. Augmenting Lagoon Process Using Reactivated Freeze-Dried Biogranules. Appl. Biochem. Biotechnol. 2017, 183, 137-154. [CrossRef]

22. Van Kessel, M.A.H.J.; Speth, D.R.; Albertsen, M.; Nielsen, P.H.; Op Den Camp, H.J.M.; Kartal, B.; Jetten, M.S.M.; Lücker, S. Complete Nitrification by a Single Microorganism. Nature 2015, 528, 555-559. [CrossRef] [PubMed]

23. Villamar, C.A.; Rivera, D.; Neubauer, M.E.; Vidal, G. Nitrogen and Phosphorus Distribution in a Constructed Wetland Fed with Treated Swine Slurry from an Anaerobic Lagoon. J. Environ. Sci. Health-Part A Toxic/Hazard. Subst. Environ. Eng. 2015, 50, 60-71. [CrossRef] [PubMed]

24. Knight, R.L.; Payne, V.W.E.; Borer, R.E.; Clarke, R.A.; Pries, J.H. Constructed Wetlands for Livestock Wastewater Management. Ecol. Eng. 2000, 15, 41-55. [CrossRef]

25. Cirelli, G.L.; Consoli, S.; Di Grande, V.; Milani, M.; Toscano, A. Subsurface Constructed Wetlands for Wastewater Treatment and Reuse in Agriculture: Five Years of Experiences in Sicily, Italy. Water Sci. Technol. 2007, 56, 183-191. [CrossRef] [PubMed]

26. Toscano, A.; Langergraber, G.; Consoli, S.; Cirelli, G.L. Modelling Pollutant Removal in a Pilot-Scale Two-Stage Subsurface Flow Constructed Wetlands. Ecol. Eng. 2009, 35, 281-289. [CrossRef]

27. Hunt, P.G.; Szögi, A.A.; Humenik, F.J.; Rice, J.M.; Matheny, T.A.; Stone, K.C. Constructed Wetlands for Treatment of Swine Wastewater from an Anaerobic Lagoon. Trans. ASAE 2002, 45, 639.

28. Poach, M.E.; Hunt, P.G.; Reddy, G.B.; Stone, K.C.; Johnson, M.H.; Grubbs, A. Swine Wastewater Treatment by Marsh-Pond-Marsh Constructed Wetlands under Varying Nitrogen Loads. Ecol. Eng. 2004, 23, 165-175. [CrossRef]

29. Han, Z.; Dong, J.; Shen, Z.; Mou, R.; Zhou, Y.; Chen, X.; Fu, X.; Yang, C. Nitrogen Removal of Anaerobically Digested Swine Wastewater by Pilot-Scale Tidal Flow Constructed Wetland Based on in-Situ Biological Regeneration of Zeolite. Chemosphere 2019, 217, 364-373. [CrossRef]

30. Zhang, M.; Luo, P.; Liu, F.; Li, H.; Zhang, S.; Xiao, R.; Yin, L.; Zhou, J.; Wu, J. Nitrogen Removal and Distribution of AmmoniaOxidizing and Denitrifying Genes in an Integrated Constructed Wetland for Swine Wastewater Treatment. Ecol. Eng. 2017, 104, 30-38. [CrossRef]

31. Meers, E.; Tack, F.M.G.; Tolpe, I.; Michels, E. Application of a Full-Scale Constructed Wetland for Tertiary Treatment of Piggery Manure: Monitoring Results. Water Air Soil Pollut. 2008, 193, 15-24. [CrossRef]

32. Hunt, P.G.; Poach, M.E. State of the Art for Animal Wastewater Treatment in Constructed Wetlands. Water Sci. Technol. 2001, 44, 19-25. [CrossRef] [PubMed]

33. Lee, C.Y.; Lee, C.C.; Lee, F.Y.; Tseng, S.K.; Liao, C.J. Performance of Subsurface Flow Constructed Wetland Taking Pretreated Swine Effluent under Heavy Loads. Bioresour. Technol. 2004, 92, 173-179. [CrossRef]

34. He, L.S.; Liu, H.L.; Xi, B.D.; Zhu, Y.B. Effects of Effluent Recirculation in Vertical-Flow Constructed Wetland on Treatment Efficiency of Livestock Wastewater. Water Sci. Technol. 2006, 54, 137-146. [CrossRef]

35. Sarmento, A.P.; Borges, A.C.; Matos, A.T. Evaluation of Vertical-Flow Constructed Wetlands for Swine Wastewater Treatment. Water Air Soil Pollut. 2012, 223, 1065-1071. [CrossRef]

36. González, F.T.; Vallejos, G.G.; Silveira, J.H.; Franco, C.Q.; García, J.; Puigagut, J. Treatment of Swine Wastewater with SubsurfaceFlow Constructed Wetlands in Yucatán, Mexico: Infuence of Plant Species and Contact Time. Water SA 2009, 35, 335-342. [CrossRef]

37. Cronk, J.K. Constructed Wetlands to Treat Wastewater from Dairy and Swine Operations: A Review. Agric. Ecosyst. Environ. 1996, 58, 97-114. [CrossRef]

38. Zema, D.A.; Andiloro, S.; Bombino, G.; Caridi, A.; Sidari, R.; Tamburino, V. Comparing Different Schemes of Agricultural Wastewater Lagooning: Depuration Performance and Microbiological Characteristics. Water Air Soil Pollut. 2016, $227,439$. [CrossRef]

39. Zema, D.A.; Andiloro, S.; Bombino, G.; Tamburino, V.; Sidari, R.; Caridi, A. Depuration in Aerated Ponds of Citrus Processing Wastewater with a High Concentration of Essential Oils. Environ. Technol. 2012, 33, 1255-1260. [CrossRef] [PubMed]

40. Sievers, D.M. Performance of Four Constructed Wetlands Treating Anaerobic Swine Lagoon Effluents. Trans. ASAE 1997, 40, 769-775. [CrossRef]

41. Shappell, N.W.; Billey, L.O.; Forbes, D.; Matheny, T.A.; Poach, M.E.; Reddy, G.B.; Hunt, P.G. Estrogenic Activity and Steroid Hormones in Swine Wastewater through a Lagoon Constructed-Wetland System. Environ. Sci. Technol. 2007, 41, 444-450. [CrossRef]

42. Clarke, E.; Baldwin, A.H. Responses of Wetland Plants to Ammonia and Water Level. Ecol. Eng. 2002, 18, 257-264. [CrossRef] 
43. Harrington, R.; Dunne, E.J.; Carroll, P.; Keohane, J.; Ryder, C. The Concept, Design and Performance of Integrated Constructed Wetlands for the Treatment of Farmyard Dirty Water. In Nutrient Management in Agricultural Watersheds: A Wetlands Solution; Wageningen Academic Publishers: Wageningen, The Netherlands, 2005; pp. 179-188.

44. Harrington, R.; McInnes, R. Integrated Constructed Wetlands (ICW) for Livestock Wastewater Management. Bioresour. Technol. 2009, 100, 5498-5505. [CrossRef] [PubMed]

45. Poach, M.E.; Hunt, P.G.; Vanotti, M.B.; Stone, K.C.; Matheny, T.A.; Johnson, M.H.; Sadler, E.J. Improved Nitrogen Treatment by Constructed Wetlands Receiving Partially Nitrified Liquid Swine Manure. Ecol. Eng. 2003, 20, 183-197. [CrossRef]

46. Kantawanichkul, S.; Neamkam, P.; Shutes, R.B.E. Nitrogen Removal in a Combined System: Vertical Vegetated Bed over Horizontal Flow Sand Bed. Water Sci. Technol. 2001, 44, 137-142. [CrossRef] [PubMed]

47. Humenik, F.J.; Szogi, A.A.; Hunt, P.G.; Broome, S.; Rice, M. Wastewater Utilization: A Place for Managed Wetlands-Review. Asian-Australas. J. Anim. Sci. 1999, 12, 629-632. [CrossRef]

48. Kottek, M.; Grieser, J.; Beck, C.; Rudolf, B.; Rubel, F. World Map of the Köppen-Geiger Climate Classification Updated. Meteorol. Z. 2006, 15, 259-263. [CrossRef]

49. Andiloro, S.; Bombino, G.; Tamburino, V.; Zema, D.A.; Zimbone, S.M. Aerated Lagooning of Agro-Industrial Wastewater: Depuration Performance and Energy Requirements. J. Agric. Eng. 2013, 44, 827-832. [CrossRef]

50. APHA. Standard Methods for the Examination of Water and Wastewater; American Public Health Association: Washington, DC, USA, 2012.

51. Liu, J.; Ge, Y.; Cheng, H.; Wu, L.; Tian, G. Aerated Swine Lagoon Wastewater: A Promising Alternative Medium for Botryococcus Braunii Cultivation in Open System. Bioresour. Technol. 2013, 139, 190-194. [CrossRef]

52. Bartsch, E.H.; Randall, C.W. Aerated Lagoons-A Report on the State of the Art. J. Water Pollut. Control Fed. 1971, 43, 699-708.

53. Osada, T.; Haga, K.; Harada, Y. Removal of Nitrogen and Phosphorus from Swine Wastewater by the Activated Sludge Units with the Intermittent Aeration Process. Water Res. 1991, 25, 1377-1388. [CrossRef]

54. Bôas, R.B.V.; Fia, R.; Fia, F.R.L.; Campos, A.T.; de Souza, G.R. Nutrient Removal From Swine Wastewater in A Combined Vertical and Horizontal Flow Constructed Wetland System. Eng. Agríc. 2018, 38, 411-416. [CrossRef]

55. Liu, F.; Zhang, S.; Wang, Y.; Li, Y.; Xiao, R.; Li, H.; He, Y.; Zhang, M.; Wang, D.; Li, X. Nitrogen Removal and Mass Balance in Newly-Formed Myriophyllum Aquaticum Mesocosm during a Single 28-Day Incubation with Swine Wastewater Treatment. J. Environ. Manag. 2016, 166, 596-604. [CrossRef] [PubMed]

56. Vymazal, J. Constructed Wetlands for Wastewater Treatment: Five Decades of Experience. Environ. Sci. Technol. 2011, 45, 61-69. [CrossRef]

57. Vymazal, J. Constructed Wetlands for Wastewater Treatment. Water 2010, 2, 530-549. [CrossRef]

58. Xu, J.; Li, C.; Yang, F.; Dong, Z.; Zhang, J.; Zhao, Y.; Qi, P.; Hu, Z. Typha Angustifolia Stress Tolerance to Wastewater with Different Levels of Chemical Oxygen Demand. Desalination 2011, 280, 58-62. [CrossRef]

59. Stone, K.C.; Poach, M.E.; Hunt, P.G.; Reddy, G.B. Marsh-Pond-Marsh Constructed Wetland Design Analysis for Swine Lagoon Wastewater Treatment. Ecol. Eng. 2004, 23, 127-133. [CrossRef]

60. Klomjek, P. Swine Wastewater Treatment Using Vertical Subsurface Flow Constructed Wetland Planted with Napier Grass. Sustain. Environ. Res. 2016, 26, 217-223. [CrossRef]

61. Ayaz, S.Ç.; Findik, N.; Akça, L.; Erdoğan, N.; Kınacı, C. Effect of Recirculation on Organic Matter Removal in a Hybrid Constructed Wetland System. Water Sci. Technol. 2011, 63, 2360-2366. [CrossRef] 